\title{
ANALISIS TINGKAT KESELAMATAN LALU LINTAS KOTA SEMARANG
}

\author{
Rudatin Ruktiningsih \\ Program Studi Teknik Sipil, Fakultas Teknik \\ Universitas Katolik Segijapranata Semarang \\ email : rudatin.ruktiningsih@gmail.com
}

\begin{abstract}
ABSTRAK
Kecelakaan lalu lintas merupakan permasalahan lalu lintas baik di tingkat global, di Indonesia maupun Kota Semarang. Hampir setiap hari berita kecelakaan lalu lintas jalan raya selalu menghiasi media cetak maupun elektronik di Kota Semarang. Semakin meningkat jumlah penduduk di Kota Semarang memberi potensi peningkatan kejadian kecelakaan lalu lintas, hal ini disebabkan semakin banyak pergerakan lalu lintas di ruas-ruas jalan Kota Semarang. Tujuan penelitian ini adalah untuk mengetahui tingkat keselamatan lalu lintas jalan raya di Kota Semarang yang direpresentasikan dalam angka kecelakaan berbasis jumlah penduduk dan panjang jalan serta indeks severitas. Metode perhitungan menggunakan metode yang dikembangkan oleh Pignataro (1973) dengan mengambil data jumlah kecelakaan dan korban yang tercatat di Kota Semarang. Hasil perhitungan menunjukkan bahwa angka kecelakaan berbasis jumlah penduduk menunjukkan penurunan yaitu dari 67,31 pada tahun 2012 menjadi 50,32 pada tahun 2015, ditinjau dari panjang jalan terjadi penurunan dari 0,39 pada tahun 2012 menjadi 0,30 pada tahun 2015, namun indeks severitas terjadi peningkatan yaitu 0,13 pada tahun 2011 menjadi 0,24 pada tahun 2015. Hal ini menunjukkan bahwa tingkat keselamatan lalu lintas di Kota Semarang terjadi penurunan, untuk itu perlu upaya penanganan serius oleh Pemerintah Kota Semarang dengan melibatkan seluruh stakeholder yang ada.
\end{abstract}

Kata kunci : Kecelakaan lalu lintas, Tingkat Keselamatan Lalu Lintas, Angka Kecelakaan

\section{PENDAHULUAN}

\section{Latar Belakang}

Keselamatan adalah faktor yang dibutuhkan oleh setiap insan manusia di dunia ini termasuk keselamatan di sektor transportasi. Hal tersebut dikarenakan sektor transportasi merupakan sektor yang sangat penting dan merupakan kebutuhan vital bagi kehidupan masyarakat.

Salah satu keselamatan transportasi yang saat ini mendapat sorotan tajam adalah Keselamatan lalu lintas jalan raya. Hal ini terjadi karena semakin hari keselamatan lalu lintas jalan raya semakin menurun, terbukti semakin tingginya jumlah kecelakaan yang terjadi di jalan raya.

Jumlah Kecelakaan di Australia tertinggi sebesar $41 \%$ terjadi pada ruas jalan, sedangkan di Swedia, 200 orang meninggal setiap tahun akibat kecelakaan pada ruas jalan. Indonesia pada kurun waktu 2005-2008 setiap tahun hampir 100 ribu terjadi kecelakaan lalu lintas (Mabes Polri,2008), sehingga Indonesia menempati urutan ke Sembilan dari sepuluh negara di Asean dalam hal tingkat keselamatan lalu lintas. 


\section{Permasalahan}

Kota Semarang adalah salah satu kota metropolitan di Indonesia, dengan jumlah penduduk lebih dari 1,5 juta orang (BPS Kota Semarang, 2016) tentunya permasalahan keselamatan lalu lintas perlu mendapatkan perhatian yang serius.

Hal ini terjadi karena semakin meningkatnya jumlah penduduk yang akan berakibat terjadinya peningkatan pergerakan dan berakibat jumlah kendaraan juga meningkat akan menyebabkan semakin padatnya lalu lintas yang tidak menutup kemungkinan akan banyak terjadi konflik antar kendaraan yang berujung pada kecelakaan lalu lintas.

Semakin tinggi jumlah kecelakaan di suatu wilayah akan mengindikasikasikan pada semakin rendahnya tingkat keselamatan lalu lintas dalam wilayah tersebut dengan kata lain bahwa indikator tingkat keselamatan lalu lintas di suatu daerah adalah tinggi atau rendahnya kecelakaan lalu lintas yang terjadi yang direpresentasikan pada angka kecelakaan

\section{Tujuan dan Manfaat Penelitian}

Tujuan penelitian ini adalah :

1. Untuk mengetahui jumlah kecelakaan lalu lintas jalan raya di Kota Semarang

2. Untuk mengetahui angka kecelakaan lalu lintas jalan raya di Kota Semarang berdasarkan jumlah penduduk dan panjang jalan

3. Untuk mengetahui indeks severitas kecelakaan lalu lintas di Kota Semarang

Sedangkan manfaat penelitian ini adalah memberikan pengetahuan tentang salah satu cara menentukan indikator penilaian keselamatan lalu lintas jalan raya di Kota Semarang dan sebagai salah satu masukan bagi Pemerintah Kota Semarang dalam upaya merumuskan penanganan keselamatan lalu lintas jalan raya.

\section{Batasan Penelitian}

Karena luasnya ruang lingkup penelitian ini, maka dilakukan pembatasan sebagai berikut,

1. Penelitian dilakukan di Kota Semarang

2. Fokus penelitian adalah kecelakaan lalu lintas jalan raya

3. Perhitungan angka kecelakaan lalu lintas jalan raya berbasis jumlah penduduk dan panjang jalan di Kota Semarang

4. Tidak membahas tentang keterlibatan kendaraan dan kriteria korban maupun pelaku kecelakaan lalu lintas jalan raya.

\section{TINJAUAN PUSTAKA}

\section{Transportasi}

Transportasi adalah pemindahan barang, orang dan jasa dari suatu tempat ke tempat lain. Pemindahan ini mempunyai asas bahwa materi yang dipindahkan harus tetap dalam arti kondisinya di tempat yang baru tetap seperti sebelum dipindahkan (Khisty and Lail, 2009).

Semakin besar jumlah pendudukakan menyebabkan peningkatan kebutuhan sehingga aktivitas untuk pemenuhan kebutuhan juga semakin meningkat, akibatnya kebutuhan alat transportasi semakin bertambah.Selain itu pembangunan wilayah dan daerah menyebabkan terjadinya pertumbuhan pusat-pusat kegiatan dan pemukiman sehingga akan memperbesar kebutuhan akan pergerakan (Salim,2002).

Tujuan transportasi adalah menyelenggarakan pemindahan dengan aman, nyaman dan ekonomis. Aman yang dimaksud disini adalah obyek yang dipindahkan adalah dalam kondisi seperti sebelum dipindahkan dan tanpa ada gangguan selama melakukan proses transportasi. Sedangkan nyaman adalah obyek yang berpindah mendapatkan pelayanan yang sesuai dengan apa seharusnya dalam arti sesuai dengan standar yang berlaku. Ekonomis 
dimaksudkan bahwa efektifitas dan efisien merupakan unsur yang diutamakan dalam arti tidak ada pemborosan terutama dari sisi biaya dan waktu karena indikator utama dalam mengukur pelayanan transportasi adalah dari waktu dan biaya.

\section{Keselamatan Lalu Lintas}

Keselamatan lalu lintas adalah suatu bentuk usaha/cara untuk mencegah terjadinya kecelakaan yang berupa keamanan, kenyamanan, dan perekonomian dalam memindahkan muatan (orang maupun barang/hewan) dengan menggunakan alat angkut tertentu melalui media atau lintasan tertentu dari lokasi/tempat asal lokasi/tempat tujuan perjalanan.

Sebagai bagian dari Sistem Transportasi Nasional, keselamatan transportasi khususnya keselamatan lalu lintas angkutan darat memiliki peranan yang sangat penting berkaitan dengan distribusi penduduk, barang/hewan guna mendukung kelancaran kegiatan pemerintahan dan pembangunan.

Pesatnya pertumbuhan penduduk dan meningkatnya kebutuhan pelayanan jasa transportasi menuntut adanya peningkatan unsur keselamatan yang bertindak sebagai pedoman dalam penyediaan jasa transportasi baik secara kuantitatif maupun kualitatif.

Keselamatan transportasi jalan terkait erat dengan bidang rekayasa jalan raya (highway engineering) dan beberapa bidang lainnya. Sedikitnya ada lima aspek pokok dalam rekayasa jalan raya yang terkait dengan masalah keselamatan yaitu aspek perancangan, aspek perencanaan, aspek pelaksanaan, operasi dan pemeliharaan. Disamping itu, ada dua bidang rekayasa lainnya yang terkait yaitu rekayasa kendaraan dan material (vehicle and material engineering), dan bebrapa bidang non rekayasa meliputi ekonomi, psikologi, kesehatan, hukum, pendidikan dan bidang sosial lainnya.
Dalam sebuah sistem keselamatan lalu lintas fakor yang saling berinteraksi adalah sebagai berikut dalam skema di bawah ini,

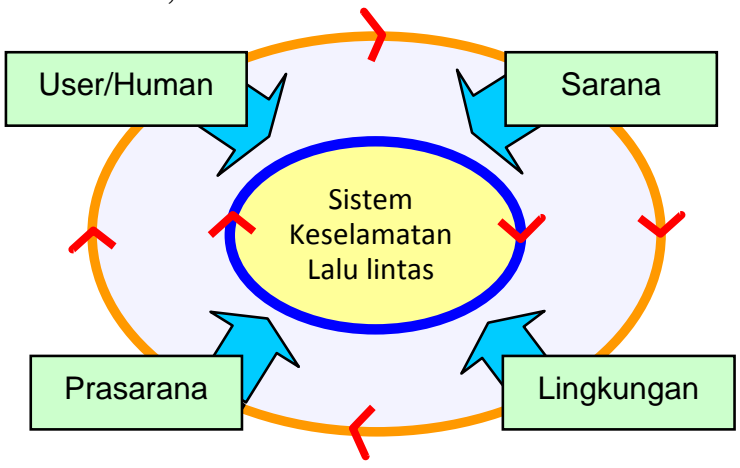

Gambar 1

Konsep sistem keselamatan lalu lintas

Beberapa penelitian menyatakan bahwa faktor pengemudi dan interaksinya dengan tiga faktor lainnya telah teridentifikasi sebagai faktor paling dominan dalam memberikan kontribusi terhadap terjadinya kecelakaan. Kontribusi faktor ini kurang lebih sebesar 92\%, dimana untuk pengemudi saja sebesar 64\%, interaksi pengemudi dengan empat faktor lainnya $28 \%$, dan sisanya $8 \%$ adalah akibat empat faktor lainnya (non-pengemudi).

Faktor pengemudi di antaranya adalah: kondisi kesehatan, emosi, kelelahan, kemampuan teknis mengemudi, pengaruh alkohol dan obat terlarang. Dalam tahun 2003, 17.013 orang di Amerika meninggal dalam kecelakaan; 40\% dari keseluruhan kematian akibat kecelakaan adalah pengemudi dalam pengaruh alkohol. Dalam kecelakaan yang menyebabkan kematian (fatal crashes), prosentase tertingi pengemudi dengan kandungan alkohol dalam darah sebesar 0,08g/dl atau lebih adalah pengendara sepeda motor (29\%), diikuti pengemudi truk ringan (22\%) dan pengemudi kendaraan ringan (sedan dll) (22\%) kemudian truk berat (1\%). Di Australia, korban kematian terbanyak (31\%) adalah pengemudi dengan usia antara 17-25 tahun. Di Indonesia (Ditlantas Polri,2008), jumlah kecelakaan terbesar (33\%) melibatkan 
pengemudi dengan usia antara 22-30 tahun. Lebih dari $72 \%$ kecelakaan yang terjadi melibatkan pemakai jalan dengan pendidikan SMP dan SMU.

Faktor lalu lintas menyangkut besar kecilnya arus lalu lintas, kecepatan dan komposisi jenis kendaraan yang ada. Semakin tinggi arus lalu lintas, kecepatan dan komposisi jenis kendaraan semakin beragam, maka potensi terjadi kecelakaan semakin besar. Pada ruas jalan dengan arus lalu lintas rata-rata 6000 kendaraan/hari, apabila arus naik 2 kali lipat maka kecelakaan akan naik 65\%, kenaikan 10\% kecepatan telah menaikkan kecelakaan sebesar 27\%. Di Australia kecelakaan tertinggi (41\%) terjadi pada ruas jalan dengan batas kecepatan (speed limit) di atas $80 \mathrm{~km} / \mathrm{jam}, 21 \%$ pada ruas jalan dengan batas kecepatan antara 60-79 $\mathrm{km} / \mathrm{jam}$, sisanya pada batas kecepatan yang lain. Penurunan kecepatan kendaraan $5 \mathrm{~km} / \mathrm{jam}$ telah menurunkan tingkat kecelakaan dengan luka serius sebesar $27 \%$, dan penurunan sebesar $40 \%$ apabila kecepatan rata-rata turun $10 \mathrm{~km} / \mathrm{jam}$. Di Swedia, 200 orang meninggal setiap tahun akibat kecelakaan pada ruas jalan dengan batas kecepatan $90 \mathrm{~km} / \mathrm{jam}, 140$ orang dan 120 orang meninggal pada ruas jalan dengan batas kecepatan masing-masing 70 $\mathrm{km} / \mathrm{jam}$ dan $50 \mathrm{~km} / \mathrm{jam}$ (Workshop FSTPT,2009).

Faktor jalan berkait dengan kualitas jalan, dalam hal ini adalah kualitas fisik (memenuhi persyaratan teknis), kualitas kenyamanan/kerataan (riding quality) serta kelengkapan jalan dan pengaturannya (marka, median, rambu, lampu lalu lintas, dll). Di Australia, kecelakaan tertinggi (69\%) terjadi pada ruas jalan dengan tanjakan/turunan sebesar $2,9 \%$ dan kecelakaan tertinggi terjadi pada ruas jalan dengan lebar lajur 3,3 m sampai dengan 3,4 m (34\%). Di California, perbaikan tikungan dan tanjakan termasuk membangun lajur khusus tanjakan untuk kendaraan berat (hill climbing lanes) telah menurunkan angka kecelakaan di lokasi studi sebesar $50 \%$, pelebaran bahu jalan menurunkan angka kecelakaan rata-rata $15 \%$, selanjutnya, kanalisasi menggunakan pulau-pulau jalan telah menurunkan angka kecelakaan di persimpangan rata-rata sebeasr 40\%. Pemasangan median (pemisah jalur) dengan desain yang benar dan perawatan yang baik telah menurunkan angka kecelakaan sebesar 40\%. Di Australia, pemasangan lampu pengatur lalu lintas di persimpangan telah menurunkan angka kecelakaan sebesar $32 \%$, di California meurunkan angka kecelakaan 39\%, di Detroit menurunkan angka kecelakaan 47\% (Workshop FSTPT,2009).

Faktor kendaraan menyangkut kualitas ataupun kelayakan kendaraan dan perlengkapannya (sabuk keselamatan, kantung udara, dll). Di Amerika, dalam tahun 2003, 14.903 nyawa telah diselamatkan karena menggunakan sabuk keselamatan saat terjadi kecelakaan. Faktor kendaraan dilaporkan memberikan kontribusi terbesar terjadinya kecelakaan di jalan tol di Indonesia (56\%), ban pecah (53\%) dan rem tidak berfungsi (20\%) merupakan dua penyebab yang terbesar.Faktor lingkungan seperti cuaca dan kondisi penerangan jalan juga berpengaruh terhadap terjadinya kecelakaan. Kontribusi faktor ini terhadap terjadinya kecelakaan berkisar antara 02\%. Di Finlandia, perbaikan sistem penerangan jalan pada persimpangan tanpa lampu lalu lintas telah menurunkan angka kecelakaan sebesar $48 \%$ untuk persimpangan 3 kaki dan $15 \%$ pada persimpangan 4 kaki. Di California, pemasangan lampu penerangan jalan mengurangi angka kecelakaan sebesar $15 \%$.

Berdasarkan UU no. 22 Tahun 2009 tentang Lalu Lintas dan Angkutan Jalan pada pasal 203 mengamanatkan bahwa pemerintah bertanggung jawab atas terjaminnya keselamatan lalu lintas dan 
angkutan jalan sehingga pemerintah harus menyusun rencana umum nasional keselamatan lalu lintas dan angkutan jalan.

\section{Kecelakaan Lalu Lintas}

Kecelakaan lalu-lintas merupakan suatu peristiwa yang tidak disangka-sangka dan tidak disengaja melibatkan kendaraan dengan atau tanpa pemakai jalan lainnya, yang mengakibatkan korban manusia (mengalami luka ringan, luka berat, dan meninggal) dan kerugian harta benda (UU No. 22,2009).

Kriteria korban kecelakaan lalu-lintas menurut Jasa Marga adalah :

1. Luka ringan adalah keadaan korban mengalami luka-luka yang tidak membahayakan jiwa dan atau tidak memerlukan pertolongan atau perawatan lebih lanjut di rumah sakit. Misalnya luka kecil dengan pendarahan sedikit dan korban sadar, luka bakar, keseleo dari anggota badan yang ringan tanpa komplikasi, penderita tersebut dalam keadaan sadar tidak pingsan atau muntah-muntah.

2. Luka berat adalah keadaan korban mengalami luka-luka yang dapat membahayakan jiwa dan memerlukan pertolongan/perawatan lebih lanjut dengan segera di rumah sakit. Misalnya luka yang menyebabkan keadaan penderita menurun, biasanya luka yang mengenai kepala dan batang kepala, patah tulang anggota badan dengan komplikasi disertai rasa nyeri yang hebat dan pendarahan hebat, benturan atau luka yang mengenai badan penderita menyebabkan kerusakan alatalat dalam.

3. Meninggal adalah keadaan dimana penderita terdapat tanda-tanda kematian secara fisik. Korban meninggal adalah korban kecelakaan yang meninggal di lokasi kejadian, meninggal selama perjalanan ke rumah sakit, atau meninggal ketika dirawat di rumah sakit.
Kejadian kecelakaan lalu-lintas sangat beragam baik dari proses kejadian maupun faktor penyebab.

Menurut proses kejadiannya, kecelakaan lalu-lintas dapat dikelompokkan sebagai berikut :

a. Kecelakaan tunggal yaitu peristiwa kecelakaan yang hanya melibatkan satu kendaraan.

b. Kecelakaan ganda yaitu peristiwa kecelakaan yang melibatkan dua kendaraan.

c. Kecelakaan beruntun atau karambol yaitu peristiwa kecelakaan yang melibatkan tiga kendaraan atau lebih.

Menurut Hobbs (1995) kondisi keparahan kecelakaan dapat digolongkan menjadi 4 kategori yaitu,

a. Kecelakaan ringan yaitu kecelakaan yang tidak memerlukan perawatan rumah sakit.

b. Kecelakaan kecil yaitu kecelakaan yang memerlukan perawatan di rumah sakit

c. Kecelakaan fatal adalah kecelakaan yang menyebabkan korbannya meninggal dunia

d. Kecelakaan lain yaitu kecelakaan yang hanya menimbulkan kerugian material.

\section{Analisis Kecelakaan Lalu Lintas}

Pendataan kecelakaan dilakukan dalam beberapa tahap antara lain berdasarkan jenis kecelakaan, kondisi korban, biaya akibat kecelakaan dan lokasi kecelakaan sehingga diperoleh gambaran atau diskripsi kecelakaan. Berdasarkan data tersebut kemudian dianalisis sehingga diperoleh beberapa parameter yang digunakan untuk mengetahui tingkat keselamatan lalu lintas di suatu wilayah.

Pignataro (1973) dalam Andung Yunianta (2011) menyatakan beberapa cara dalam melakukan perhitungan untuk menganalis kecelakaan lalu lintas yaitu sebagai berikut di bawah ini, 
a. Angka Kecelakaan berdasarkan100.000 jumlah penduduk dalam suatu wilayah

$$
A R=(A \times 100.000) / P
$$

b. Angka Kecelakaan berdasarkan panjang jalan dalam suatu wilayah

$$
A R=(A / L)
$$

c. Indeks Severitas

(kekerasan)

Kecelakaan

$$
\mathrm{SI}=(\mathrm{FI} / \mathrm{A})
$$

Keterangan :

AR: Accident Rate (Angka kecelakaan)

A : Jumlah Kecelakaan dalam 1 tahun

P : Jumlah penduduk

L : Panjang jalan $(\mathrm{km})$

SI : Indeks Severitas (kekerasan) Kecelakaan

FI : Fatalities Injury (Jumlah korban meninggal)

\section{METODE PENELITIAN}

Lokasi penelitian berada di Kota Semarang. Data yang dibutuhkan adalah data sekunder yang diperoleh dari instansi terkait selama 5 tahun terakhir , kemudian dilakukan pengolahan dengan formula yang dikemukakan oleh Pignataro (1973). Hasil pengolahan data tersebut kemudian dianalisis dan dibahas menggunakan teoriteori lalu lintas yang ada. Secara sistematis proses penelitian dapat dilihat pada gambar di bawah ini,

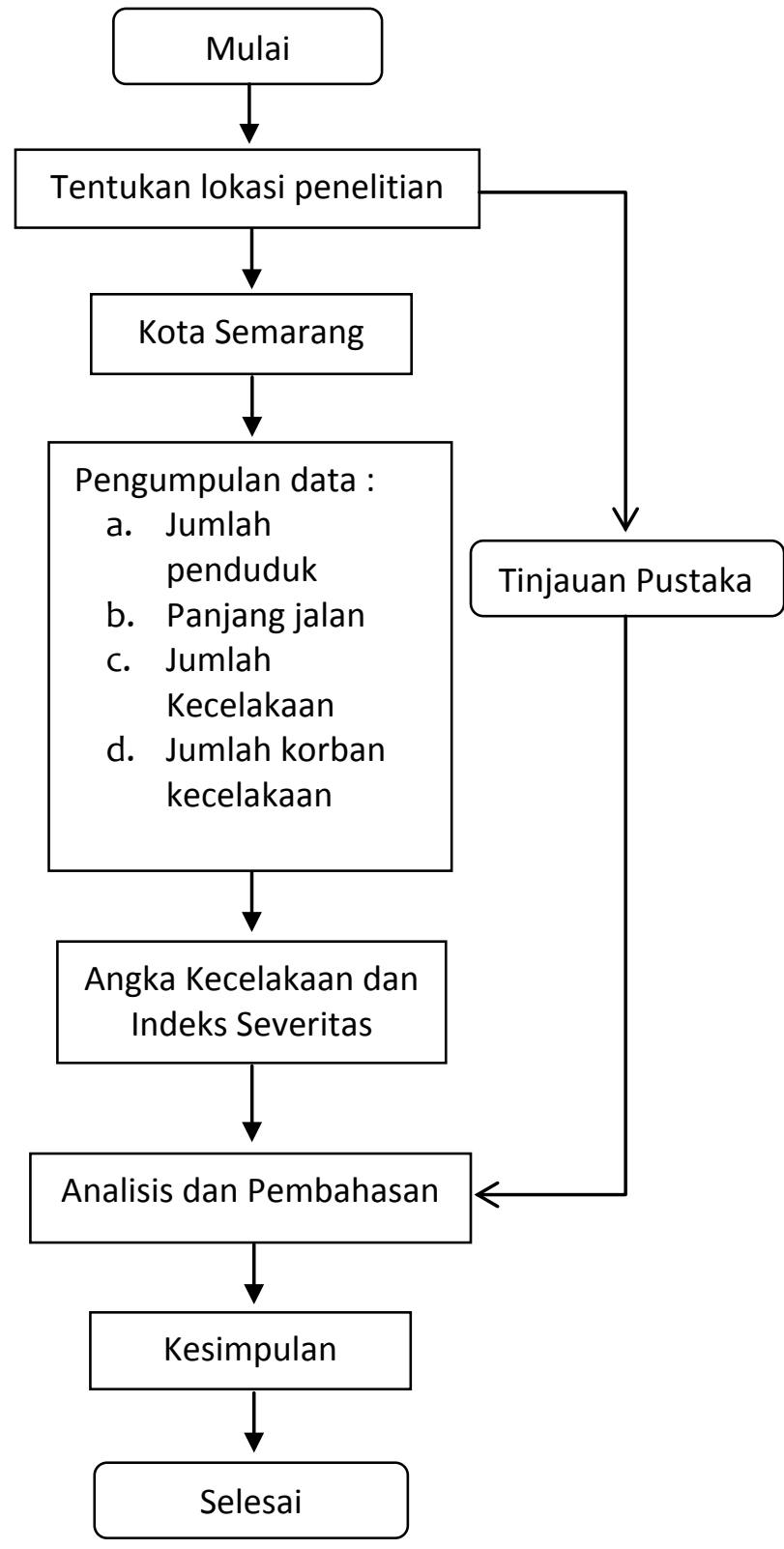

Gambar 2 Bagan Alir Penelitian

\section{ANALISIS DAN PEMBAHASAN}

Semarang merupakan ibukota Provinsi Jawa Tengah dan salah satu kota besar di Jawa Tengah. Berdasarkan jumlah penduduk, Kota Semarang termasuk kategori kota metropolitan. Jumlah penduduk berdasarkan data statistik Kota Semarang pada 2011 sampai dengan 2015 adalah sebagai berikut di bawah ini, 
Tabel 1

Jumlah Penduduk Kota Semarang (2011-2015)

\begin{tabular}{|c|c|}
\hline Tahun & Jumlah Penduduk \\
\hline 2011 & 1543557 \\
\hline 2012 & 1558380 \\
\hline 2013 & 1571341 \\
\hline 2014 & 1584068 \\
\hline 2015 & 1591860 \\
\hline
\end{tabular}

(Sumber : BPS Kota Semarang,2016)

Berdasarkan data yang ada, ternyata panjang jalan di Kota Semarang tidak mengalami pertambahan dari tahun 2011 sampai tahun 2015 sebesar 2690,342 km, hal ini dapat dilihat pada Tabel 2 di bawah ini,

Tabel 2

Panjang Jalan Kota Semarang (2011-2015)

\begin{tabular}{|c|c|}
\hline Tahun & Panjang jalan $(\mathrm{km})$ \\
\hline 2011 & 2690,342 \\
\hline 2012 & 2690,342 \\
\hline 2013 & 2690,342 \\
\hline 2014 & 2690,342 \\
\hline 2015 & 2690,342 \\
\hline
\end{tabular}

(Sumber : BPS Kota Semarang,2016)

Kondisi keselamatan lalu lintas di Kota Semarang direpresentasikan dalam jumlah kecelakaan yang terjadi di Kota Semarang. Hal ini dapat dilihat pada tabel di bawah ini,

Tabel 3 Jumlah kecelakaan, korban dan kerugian akibat kecelakaan lalu lintas Kota Semarang

\begin{tabular}{|c|c|c|c|c|c|}
\hline Tahun & $\begin{array}{c}\text { Jumlah } \\
\text { Kecela } \\
\text { kaan }\end{array}$ & $\begin{array}{c}\text { Korban } \\
\text { mening } \\
\text { gal }\end{array}$ & $\begin{array}{c}\text { Luka } \\
\text { Berat }\end{array}$ & $\begin{array}{c}\text { Luka } \\
\text { Ringan }\end{array}$ & $\begin{array}{c}\text { Kerugian } \\
\text { (JutaRp.) }\end{array}$ \\
\hline 2011 & 484 & 62 & 166 & 469 & 640 \\
\hline 2012 & 1049 & 176 & 92 & 1252 & 1573 \\
\hline 2013 & 957 & 196 & 49 & 1221 & 1011 \\
\hline 2014 & 801 & 192 & 29 & 927 & 1418 \\
\hline 2015 & 801 & 192 & 29 & 927 & 1418 \\
\hline
\end{tabular}

(Sumber : Polrestabes Kota Semarang,2016)
Berdasarkan Tabel di atas terlihat dari jumlah kecelakaan terjadi penurunan dari tahun 2012, tetapi korban meninggal semakin meningkat, hal ini mengindikasikan bahwa tingkat severitas kecelakaan semakin meningkat.

Berdasarkan data di atas dilakukan pengolahan data dengan cara perhitungan angka kecelakaan berbasis jumlah penduduk, panjang jalan dan indeks severitas berdasarkan rumus yang dikemukakan Pignataro (1973). Adapun hasilnya dapat di lihat pada tabel-tabel di bawah ini,

Tabel 4 Angka Kecelakaan berbasis Jumlah Penduduk

\begin{tabular}{|c|c|c|c|}
\hline Tahun & $\begin{array}{c}\text { Jumlah } \\
\text { Penduduk }\end{array}$ & $\begin{array}{c}\text { Jumlah } \\
\text { kecelakaan }\end{array}$ & $\begin{array}{c}\text { Angka } \\
\text { Kecelakaan }\end{array}$ \\
\hline 2011 & 1543557 & 484 & 31,36 \\
\hline 2012 & 1558380 & 1049 & 67,31 \\
\hline 2013 & 1571341 & 957 & 60,90 \\
\hline 2014 & 1584068 & 801 & 50,57 \\
\hline 2015 & 1591860 & 801 & 50,32 \\
\hline
\end{tabular}

(Sumber : Hasil Analisis,2017)

Berdasarkan hasil padaTabel 4 terlihat bahwa angka kecelakaan berdasarkan jumlah penduduk terjadi penurunan dari tahun 2012 sampai dengan 2015, hal ini menunjukkan bahwa jumlah kecelakaan yang terjadi di Kota Semarang terjadi penurunan meskipun jumlah penduduk semakin meningkat. Sedangkan angka kecelakaan berdasarkan panjang jalan terlihat terjadi peningkatan dari 0,18 pada tahun 2011 menjadi 0,39 pada tahun 2012, namun mulai menurun pada tahun 2013 sampai dengan 2015. Hal ini menunjukkan bahwa kejadian kecelakaan lalu lintas mulai menurun meskipun panjang jalan di Kota Semarang tidak terjadi pertambahan. Hal ini terlihat pada Tabel 5 di bawah ini 
Tabel 5 Angka Kecelakaan berbasis Panjang Jalan

\begin{tabular}{|c|c|c|c|}
\hline Tahun & $\begin{array}{c}\text { Panjang } \\
\text { Jalan (km) }\end{array}$ & $\begin{array}{c}\text { Jumlah } \\
\text { kecela } \\
\text { kaan }\end{array}$ & $\begin{array}{c}\text { Angka } \\
\text { Kecela } \\
\text { kaan }\end{array}$ \\
\hline 2011 & 2690,342 & 484 & 0,18 \\
\hline 2012 & 2690,342 & 1049 & 0,39 \\
\hline 2013 & 2690,342 & 957 & 0,36 \\
\hline 2014 & 2690,342 & 801 & 0,30 \\
\hline 2015 & 2690,342 & 801 & 0,30 \\
\hline
\end{tabular}

(Sumber : Hasil Analisis,2017)

Tingkat kekerasan kecelakaan lalu lintas direpresentasikan dalam indeks severitas yaitu kerasnya kecelakaan yang terindikasi dari banyaknya yang meninggal dibandingkan dengan jumlah kecelakaan. Berdasarkan perhitungan pada Tabel 6 di bawah ini, terlihat terjadi kenaikan indeks severitas yaitu 0,13 pada tahun 2011 menjadi 0,24 pada tahun 2015. Hal ini menunjukkan bahwa kecelakaan lalu lintas yang terjadi adalah semakin keras benturannya yang mengindikasikan kecepatan kendaraan pada saat kecelakaan relatif tinggi.

Tabel 6 Indeks Severitas Kecelakaan Lalu Lintas Kota Semarang

\begin{tabular}{|c|c|c|c|}
\hline Tahun & $\begin{array}{c}\text { Jumlah } \\
\text { kecela } \\
\text { kaan }\end{array}$ & $\begin{array}{c}\text { Korban } \\
\text { Mening } \\
\text { gal }\end{array}$ & $\begin{array}{c}\text { Indeks } \\
\text { Severitas }\end{array}$ \\
\hline 2011 & 484 & 62 & 0,13 \\
\hline 2012 & 1049 & 176 & 0,17 \\
\hline 2013 & 957 & 196 & 0,21 \\
\hline 2014 & 801 & 192 & 0,24 \\
\hline 2015 & 801 & 192 & 0,24 \\
\hline
\end{tabular}

(Sumber : Hasil Analisis,2017)

Berdasarkan hasil perhitungan di atas terlihat bahwa angka kecelakaan berbasis jumlah penduduk terjadi penurunan, demikian pula angka kecelakaan berdasarkan panjang jalan juga terjadi penurunan, namun berdasarkan indeks severitas terlihat bahwa nilainya terjadi peningkatan sehingga hasil tersebut merepresentasikan bahwa tingkat keselamatan lalu lintas di Kota Semarang semakin menurun. Untuk itu perlu penanganan masalah keselamatan lalu lintas di Kota Semarang artinya sesuai dengan amanah UU no. 22 Tahun 2009 Pemerintah Kota Semarang harus segera menyusun Rencana Umum Keselamatan Lalu Lintas dan Angkutan Jalan yang sesuai dengan lokalitas Kota Semarang dengan mengikutkan semua stakeholder yang ada di Kota Semarang.

\section{KESIMPULAN}

Berdasarkan uraian di atas maka kesimpulan yang dapat disampaikan adalah sebagai berikut di bawah ini,

1. Kota Semarang adalah Kota Metropolitan karena jumlah penduduk sudah melebihi 1 juta orang

2. Panjang jalan di Kota Semarang kurun waktu 2011-2015 tidak mengalami penambahan dan tetap pada angka $2690,342 \mathrm{~km}$

3. Jumlah Kejadian kecelakaan di Kota Semarang terjadi peningkatan dari tahun 2011 sebesar 464 menjadi 801 pada tahun 2015.

4. Angka kecelakaan berdasarkan jumlah penduduk terjadi penurunan dari 67,30 pada tahun 2012 menjadi 50,32 pada tahun 2015 hal ini menunjukkan kenaikan jumlah penduduk lebih tinggi daripada kenaikan jumlah kejadian kecelakaan lalu lintas.

5. Angka kecelakaan berbasis panjang jalan terjadi penurunan dari 0,39 pada tahun 2012 menjadi 0,30 pada tahun 2015 hal ini menunjukkan terjadi penurunan kejadian kecelakaan lalu lintas.

6. Indeks severitas kecelakaan lalu lintas menunjukkan bahwa terjadi kenaikan dari 0,13 pada tahun 2011 menjadi 0,24 pada tahun 2015. Hal ini mengindikasikan bahwa kejadian fatalitas kecelakaan lalu lintas 
disebabkan oleh kecepatan kendaraan yang relatif tinggi.

7. Tingkat keselamatan lalu lintas di Kota Semarang terjadi penurunan selama kurun waktu 2011 sampai 2015, untuk itu perlu upaya Pemerintah Kota Semarang untuk melakukan tindakan nyata yaitu menyusun Rencana umum peningkatan keselamatan lalu lintas dan angkutan jalan yang melibatkan seluruh stakeholder di Kota Semarang

\section{DAFTAR PUSTAKA}

Andung Yunianta,2011, Tinjauan Karakteristik Lalu Lintas dan Daerah Rawan Kecelakaan pada Ruas Jalan Raya Sentani Abepura Kabupaten Jayapura, Jurnal Teknik Sipil UBL Vol 2 No. 1 Tahun 2011

BPS Kota Semarang, 2016, Kota Semarang Dalam Angka 2016, Badan Pusat Statistik-Pemerintah Kota Semarang, Semarang.

Hobbs F.D, Traffic Planning and Engineering Second Edition; Pergamon Press; British, 1979.

Khisty Jotin C dan Lall Kent B, DasarDasar Rekayasa Tansportasi Jilid 1, Jakarta: Erlangga, 2006.

Khisty Jotin C dan Lall Kent B,DasarDasar Rekayasa Transportasi Jilid 2,Jakarta: Erlangga, Jakarta, 2006

Salim, Manajemen Transportasi, Jakarta: P.T. Raja Grafindo Persada, 1993

Undang-Undang Nomor 22 Tahun 2009 tentang Lalu Lintas dan Angkutan Jalan, Pemerintah Republik Indonesia, JakartaIndonesia 